\title{
Use of Deadly Force by Peacekeepers Operating Outside of Armed Conflict Situations: What Laws Apply?
}

Wills, S. (2018). Use of Deadly Force by Peacekeepers Operating Outside of Armed Conflict Situations: What Laws Apply? Human Rights Quarterly, 40(3), 663-702. https://doi.org/10.1353/hrq.2018.0036

Link to publication record in Ulster University Research Portal

\section{Published in:}

Human Rights Quarterly

Publication Status:

Published (in print/issue): 01/08/2018

DOI:

10.1353/hrq.2018.0036

\section{Document Version}

Author Accepted version

\section{General rights}

Copyright for the publications made accessible via Ulster University's Research Portal is retained by the author(s) and / or other copyright owners and it is a condition of accessing these publications that users recognise and abide by the legal requirements associated with these rights.

\section{Take down policy}

The Research Portal is Ulster University's institutional repository that provides access to Ulster's research outputs. Every effort has been made to ensure that content in the Research Portal does not infringe any person's rights, or applicable UK laws. If you discover content in the Research Portal that you believe breaches copyright or violates any law, please contact pure-support@ulster.ac.uk. 
Use of Deadly Force by Peacekeepers Operating Outside of Armed Conflict Situations: What Laws Apply?

Siobhán Wills*

\begin{abstract}
The UN has not published any formal statement as to the legal framework governing peacekeepers' use of force when they are not engaged as combatants in an armed conflict - but it has developed a working doctrine that it applies to all Chapter VII mandated missions regardless of whether they are deployed into situations of armed conflict or not. The doctrine, and its effects, are analysed here - drawing on interviews with UN Legal Officers; relevant UN and human rights documents; information learned in the course of field research on the impact of UN operations to combat criminal violence in Haiti.
\end{abstract}

\title{
I. Introduction
}

This article examines the approach taken by the United Nations to the use of deadly force by UN peacekeeping missions and assesses the extent to which the United Nations theoretical approach, and its practice in the field in the twenty-first century, complies with international legal standards protecting the right to life.

The article focuses on peacekeeping missions mandated under Chapter VII of the UN Charter (Chapter VII) but operating in situations where international humanitarian law (IHL) is not applicable. Under the Secretary General's 1999 Bulletin on Observance by United Nations Forces of International Humanitarian Law UN peacekeepers must comply with at least the fundamental rules and principles of IHL set out in the Bulletin 'when in situations of armed conflict they are actively engaged therein as combatants, to the extent and for the duration of their engagement.' ${ }^{1}$ 
The UN has not published any formal statement as to the legal framework governing peacekeepers' use of force when they are not engaged as combatants in an armed conflict - but it has developed a working doctrine on use of force that it applies across the board to all Chapter VII mandated missions regardless of whether they are deployed into active situations of armed conflict or not. Because it has never been formally published, the United Nations doctrine on the legal framework governing peacekeepers' use of deadly force when operating outside of a hostilities-in-armed-conflict context has not been subjected to rigorous analysis and critique in a public forum. The doctrine and its effects in practice, are analysed in the article below. The analysis is based on interviews with members of the United Nations Office of Legal Affairs; relevant $\mathrm{UN}$ documents, particularly those relating to Rules of Engagement [ROE] for peacekeeping missions; and information learned in the course of field research in Haiti, where the UN Stabilisation Mission in Haiti (MINUSTAH) has been engaged in law enforcement and humanitarian assistance for more than twelve years - during which time there has been no armed conflict as defined in international law. MINUSTAH was mandated under Security Council resolution 1542 of 30 April 2004, which made no reference to armed conflict but noted 'the existence of challenges to the political, social and economic stability of Haiti and determin[ed] that the situation in Haiti continues to constitute a threat to international peace and security in the region.'2 Topping the list of MINUSTAH' s mandated tasks was 'in support of the Transitional Government, to ensure a secure and stable environment within which the constitutional and political process in Haiti can take place. ${ }^{3}$ The Secretary-General's report published the same month as S/RES 1542 was adopted, stated that 'the greatest threat to security' in Haiti came from 'community-organized armed groups' that were 'highly fragmented, located primarily in impoverished urban areas' and relied on 'banditry and other criminal activities in order to sustain 
themselves. ${ }^{4}$ MINUSTAH is credited with successfully reducing this 'banditry' through the use of highly militarized operations against criminal gangs in the period 2004 and 2007. But the death toll as result of MINUSTAH's raids was high. ${ }^{5}$

MINUSTAH stated, in response to a query by the then UN Special Rapporteur on Extrajudicial Summary or Arbitrary Executions, Philip Alston, that on one occasion in a night raid on July $6^{\text {th }} 2005$ to arrest 'bandit' leader Dred Wilme, ${ }^{6}$ MINUSTAH encountered heavy resistance from Wilme and his associates and so, in self-defense, they expended 22,700 automatic firearm cartridges, 78 grenades, and 5 mortar shells - in a densely populated neighbourhood in which many of the houses were thin metal shacks. ${ }^{7}$ A cable from Douglas Griffiths, then Deputy US Ambassador to Haiti, said that 'MINUSTAH was being accused of killing more than twenty women and children,' statistics which his sources described as 'credible.' ${ }^{8}$ MINUSTAH conducted a similar raid on 22nd December 2006 (which it said was 'part of the strategy to fight crime and insecurity, seen in the recent wave of kidnappings in Portau-Prince') ${ }^{9}$ and another on 7th February 2007. Both raids resulted in deaths - estimates vary but it seems likely that the death tolls were similar to that of the July $5^{\text {th }}$ raid. ${ }^{10}$

Throughout this period MINUSTAH officials - including Juan Gabriel Valdès the UN Special Representative of the United Nations in Haiti from 2004 to 2006 and his successor Edmond Mulet - routinely referred to deaths and injuries caused to people that were not involved in crime as 'collateral damage' ${ }^{11}$ a term traditionally reserved for situations of armed conflict. Under IHL foreseeable deaths and injuries to non-combatants are lawful provided that the victims were not directly targeted and provided that the 'expected...incidental loss of civilian life, injury to civilians, damage to civilian objects, or a combination thereof' was not ' excessive in relation to the concrete and direct military advantage anticipated;' 12 but under international 
human rights law (IHRL), (which sets the standards for use of force outside of a hostilities-inarmed-conflict context) use of force that is likely to result in deaths is only permitted where it is strictly necessary in order to protect life. ${ }^{13}$

Civilian casualties on the scale that took place in Haiti as a direct result of use of force by peacekeepers are unusual, but the propensity for them to occur remains because ROE for peacekeeping missions have become dense, complex, and occasionally incoherent. They allow for use of deadly force in increasingly wider ranges of circumstances, in line with the broader more complex mandates, routinely adopted under Chapter VII, that have characterized UN peacekeeping since the late 1990s. This expansion in complexity, scale and preparedness to use force has not been matched by an equivalent level of attention to the legal frameworks that apply in these broadened circumstances - or to the obligations, particularly international human rights law obligations, that flow from them.

The research for this project was funded by two UK research councils - the British Academy and the Arts and Humanities Research Council. ${ }^{14}$ The applicability of IHRL in armed conflict is a topical issue and research on it has recently been undertaken by the International Law Association (ILA), the International Committee of the Red Cross (ICRC), and Chatham House Royal Institute of International Affairs: ${ }^{15}$ but none of these have undertaken the in-depth analysis of the United Nations approach to peacekeepers' use of deadly force that this article offers.

The article is set out in six further sections:

2. Overview of the Argument

3. The UN Stabilization Mission in Haiti

4. Overview of the Relevant Legal Frameworks 
5. The Views of the International Committee of the Red Cross and

Human Rights Organizations

6. The Approach taken by the UN Office of Legal Affairs

7. Conclusion

\section{OVERVIEW OF THE ARGUMENT}

This paper argues that use of deadly force by UN police or military personnel when carrying out law enforcement operations must comply with customary international human rights law (IHRL) obligations protecting the right to life. That law enforcement operations are constrained by IHRL norms on use of force even in situations of armed conflict, and that IHRL prohibits use of deadly force except where it is necessary to protect life or to protect from serious injury, is not a controversial position. It is recognised by the United Nations itself in key documents ${ }^{16}$ and by former UN Special Rapporteurs on Extrajudicial Summary or Arbitrary Executions, Christof Heyns and Philip Alston; ${ }^{17}$ by the International Committee of the Red Cross (which is the leading organization responsible for articulating and monitoring the legal obligations that apply in situations of armed conflict); ${ }^{18}$ by the International Law Association in various committee reports; ${ }^{19}$ and by leading experts in the laws applicable in armed conflicts most succinctly in the Practitioners Guide to Human Rights Law in Armed Conflict, co-written and co-edited by Dapo Akande, Charles Garraway, Françoise Hampson, Noam Lubell, Daragh Murray and Elizabeth Wilmshurst, all internationally recognized experts in the field that between them have extensive military, foreign office, international court, NGO and academic experience. ${ }^{20}$

However, although the ICRC, ILA, the UN Special Rapporteurs cited above, and the 
Practitioners Guide to Human Rights Law in Armed Conflict, all state that IHRL obligations on the right to life apply to all agencies carrying out law enforcement operations, including UN peacekeeping missions, the UN Department of Peacekeeping Operations (UNDPKO), and the UN Office of Legal Affairs, have not acknowledged that when UN peacekeeping missions use deadly force to carry out law enforcement tasks they must comply with customary international IHRL obligations protecting the right to life.

The UN Office of Legal Affairs regards the mandate as the key factor governing use of deadly force and believes that pursuant to their mandate peacekeepers may use deadly force against anyone, whether or not they are parties to an armed conflict, provided that use of force for the purpose of carrying out the mandated task is authorized by the Security Council resolution setting out the mandate; that use of deadly force is proportionate to achieving the objective authorized by the mandate; that minimum force is used and only as a last resort; and that use of deadly force is authorized by the mission's Rules of Engagement (ROE). ${ }^{21}$

ROE for UN peacekeeping missions routinely prohibit use of weapons or methods of combat or warfare prohibited under IHL but there is no reference to peacekeepers obligations under IHRL in either the United Nations generic template for ROE or in mission specific ROE. ${ }^{22}$ Some of the specific authorizations set out in the ROE for missions deployed since 2000, are, prima facie at least, incompatible with customary IHRL obligations protecting the right to life. ${ }^{23}$ To a limited degree this may also have been true of earlier missions, particularly in relation to use of deadly force to protect designated property, ${ }^{24}$ but since the millennium the problem has become acute. Prior to the twenty-first century mission mandates generally did not authorize use of force to carry out tasks of a law enforcement nature and hence their ROE did not authorize it either. Today the situation is very different. 
Since 2000 the Security Council has frequently authorized use of force not only against parties to an armed conflict but also against groups deemed to pose a threat to peace and order 'more generally. ${ }^{25}$ Examples include the UN Mission in Cote d'Ivoire (UNOCI) which has been mandated since June 2015 (four years after the conflict in Côte d'Ivoire came to an end), to use 'all necessary means' to fulfil all of its complex mandate, which includes 'support[ing] the national authorities in stabilizing the security situation in the country;' 26 and the UN Multidimensional Integrated Stabilization Mission in the Central African Republic (MINUSCA) which is mandated 'to take all necessary means' within its capabilities and areas of deployment, to inter alia 'promote and support the rapid extension of State authority. ${ }^{27}$ Ola Enghdahl (former legal advisor to the Stabilisation Force in Bosnia-Herzegovina and currently legal advisor to the Swedish Ministry of Foreign Affairs) notes that the use of UN military forces for conducting traditional policing tasks has become 'one of the 'trademarks' of peace operations. ${ }^{28} \mathrm{~A}$ detailed table of all current $\mathrm{UN}$ peacekeeping missions setting out the categories of tasks that they are mandated to carry out, is available from the UN website in an excel table. ${ }^{29}$ Many of the categories listed in the table relate to law enforcement activities - for example fifteen missions are mandated to carry out Rule of Law tasks, fifteen to carry out tasks relating to Electoral Assistance, eleven to provide Support to State Institutions, and eleven to carry out Security Sector reforms. ${ }^{30}$ Most of these missions are mandated under Chapter VII and most are authorized to use force using the formula 'all necessary means' or 'all necessary measures. ' 31 'All necessary means' or 'all necessary measures' are euphemisms routinely used by the Security Council to authorize force. ${ }^{32}$

Individuals and groups that are not parties to an armed conflict but whose activities undermine peace and stability are categorized by the UN as 'spoilers' - defined in the UN 
Department of Peacekeeping (DPKO)'s 2010 Draft Concept Note on Robust Peacekeeping as 'those who seek to obstruct or derail the implementation of a mission mandate. ${ }^{33}$ Emily Paddon Rhoads notes the "broadening of what constitutes spoiling activity to include, for example, domestic and transnational organized crime' which she argues 'further substantiates the parallel between contemporary peacekeeping and law enforcement.' ${ }^{34}$ This is particularly true of operations that have a stabilization component. Karlsrud defines stabilization as the use of 'military means to stabilize a country, sometimes with all necessary means to neutralize potential "spoilers." 35

Bellamy and Hunt argue that the tendency of twenty-first century UN missions to 'move away from peacekeeping as an impartial overseer of peace processes towards the goal of stabilization ${ }^{36}$ has brought about a significant increase in use of force since stabilization requires that 'the use of force by UN peacekeepers moves from being a potential resource that might be used sparingly in response to unforeseen circumstances to a tool whose use is directly presaged by the mandate itself.' ${ }^{37}$ At the time of writing, four UN missions are explicitly mandated, under Chapter VII of the UN Charter, as stabilization missions - the missions to the Democratic Republic of Congo, the Central African Republic, Mali and Haiti. ${ }^{38}$ In addition to these, several missions that are not explicitly designated as stabilization missions are nevertheless mandated to carry out stabilization objectives. Examples include the UN Mission in Lebanon (UNIFIL) ${ }^{39}$ and the UNOCI. ${ }^{40}$ The UN peacekeeping website lists "[s]upport for the restoration and extension of State authority' as one of the activities in which 'UN peacekeepers are often mandated to play a catalytic role. ${ }^{41}$ Alongside this extension into stabilization the ' $\mathrm{UN}$ is pushing hard to promote the concept of robust peacekeeping as a requirement for all peacekeepers. ${ }^{42}$ This push towards increased and more intense use of force by peacekeepers, and the expansion of peacekeeping 
activities to encompass stabilization, has not been matched by equivalent attention to the legal obligations relating to use of force outside of a hostilities-in-armed conflict context.

The United Nations Capstone Doctrine, which sets out the Principles and Guidelines that should govern peacekeeping operations, states that:

The environments into which United Nations peacekeeping operations are deployed are often characterized by the presence of militias, criminal gangs, and other spoilers who may actively seek to undermine the peace process or pose a threat to the civilian population. In such situations, the Security Council has given United Nations peacekeeping operations "robust" mandates authorizing them to "use all necessary means" to deter forceful attempts to disrupt the political process, protect civilians under imminent threat of physical attack, and/or assist the national authorities in maintaining law and order. ${ }^{43}$

The UN DPKO's Draft Concept Note on Robust Peacekeeping asserts that:

Where a robust approach necessitates the use of force by peacekeeping operations, it is pursued on a case-by-case basis only, in full adherence to the operation's mandate, its Rules of Engagement and Directives on Use of Force where applicable and the principles of UN peacekeeping, and in full compliance with the applicable humanitarian, human rights and refugee law. ${ }^{44}$

However, neither humanitarian, human rights or refugee law, permit the use of deadly force against spoilers or criminals that are not parties to an armed conflict or civilians directly participating in one, in order to 'deter forceful attempts to disrupt the political process,' or to 'assist the national authorities in maintaining law and order,' two of the three example scenarios given in the Capstone Doctrine. So how should use of 'all necessary means,' be interpreted in these contexts? 


\section{THE UN STABILIZATION MISSION IN HAITI (MINUSTAH)}

The UN Stabilization Mission in Haiti was deployed to provide security in the aftermath of the forced departure of former President Aristide in February 2004. The armed violence associated with the coup against Aristide lasted just three weeks and involved no more than three hundred armed men. It began as 'a few isolated attacks on police posts, evolving into a small number of troops moving largely uncontested across the territory. They ultimately did not seek armed confrontation but rather fear and mobilization of masses. ${ }^{35}$ It is possible that during those three weeks the situation in Haiti did meet the legal criteria for armed conflict; but if so any armed conflict was over by the time MINUSTAH deployed in June. However according to the International Crisis Group the situation 'never escalated into an internal armed conflict' and throughout the period of violence there were no 'clearly identified parties to a conflict." ${ }^{46}$

The ICRC, in its 26 February 2004 Bulletin (published three days before Aristide was taken to the Central African Republic) described the situation in Haiti as 'armed violence' rather than 'armed conflict.' ${ }^{47}$ In a subsequent report on its role in providing assistance in situations of urban violence short of armed conflict, the ICRC made it clear that it did not consider the situation in Haiti during the period 2004 to 2007 to be one of armed conflict:'

Rio de Janeiro is not the only place where the ICRC has reacted to urban violence short of war. Between 2004 and 2007, after the ouster of former president Jean-Bertrand Aristide, the ICRC and the Haitian National Red Cross Society came to the aid of victims of violence in Portau-Prince....entering into discussions with gang leaders is not difficult, but the conversations will not be the same as with opposition groups fighting armed conflicts. ${ }^{48}$

A 2009 report by the Center on International Cooperation states that in Haiti: 
the most salient political violence of the past three decades has involved not wellorganized combat operations, but mobilization of crowds from among the millions of extremely poor, on short notice by murky political interests. Violent political activity often reflects intertwined criminal and political insecurity. ${ }^{49}$

This case study was cited by the UN DPKO itself, in its report Second Generation Disarmament, Demobilization, and Reintegration Practices in UN Peacekeeping Operations. ${ }^{50}$ The case study was also cited approvingly by Carlos Channos Vianna Braga, a Brazilian Navy Officer that served in Haiti as assistant to MINUSTAH's first force commander, General Augusto Heleno Ribeiro Pereira. ${ }^{51}$

MINUSTAH's early operations were mainly to provide support to Haitian National Police (HNP) - which they provided despite allegations of serious human rights abuses committed by the HNP. Kofi-Annan, in his February 2005 report on Haiti, stated that he remained 'concerned about the human rights situation, including allegations of human rights abuses attributed to HNP officers, which have not yet been properly investigated by the authorities. ${ }^{52}$ A Security Council Mission visited Haiti in April 2005 and reported that it: received reports that a culture of impunity remained pervasive, marked by arbitrary arrest, wrongful detention, inhumane prison conditions, excessive use of force, and extrajudicial executions. As a result, the population continues to view the national police with fear and lack of respect. The mission learned that the commission that should investigate allegations against the police had yet to be established. ${ }^{53}$

In August 2005 the HNP was accused of firing wantonly into a crowd of spectators at a football match. ${ }^{54}$ Thierry Fagart, who was chief of the Human Rights Section of MINUSTAH, estimated that at least nine people died. ${ }^{55}$ Philippe Branchat, an employee of the International 
Organization for Migration, who managed the USAID-program that sponsored the soccer game, said that according to the information he got from his contacts this was 'a planned aggression, an attack to destabilize the community. ${ }^{56}$ In November 2005 Amnesty International called for an investigation into human rights violations by the HNP. ${ }^{57}$

In 2013 the UN adopted a Human Rights Due Diligence Policy that applies to all United Nations entities, which states that before UN forces give support to a host state an assessment of 'the risk of the recipient entity committing grave violations of international humanitarian law, human rights law or refugee law' must be made and 'procedures for monitoring the recipient entity's compliance with international humanitarian, human rights and refugee law' must be established as part of an effective implementation framework. ${ }^{58}$ If 'the United Nations receives reliable information that provides substantial grounds to suspect that the recipient entity' is engaging in grave violations of international humanitarian, human rights or refugee law, and continues to do so despite protests, then the United Nations entity must suspend or withdraw support from the recipient. ${ }^{59}$ In 2004 the UN did not have in place a formal policy prohibiting UN peacekeepers' from providing support to governments that violate human rights - but that does not alter the fact that the UN has an obligation not to provide military support to governments that violate human rights, especially when it is of such a scale and seriousness as to warrant international concern, including by the UN Secretary-General and Security Council delegations.

In 2009 the Under Secretary General for Legal Affairs and UN Legal Counsel, Patricia O'Brien, stated, in a note to the Under Secretary General for Peacekeeping Operations, Alain Le Roy, that the UN Mission in the Democratic Republic of the Congo: may not lawfully provide logistics or 'service' support to any FARDC [Congolese armed 
forces] operation if it has reason to believe that the FARDC units involved are in violation of any of those bodies of law [IHL, IHRL and international refugee law]...this follows from the Organization's obligations under customary international law and from the Charter to uphold, promote and encourage respect for human rights, international humanitarian law and refugee law. ${ }^{60}$

Ms O'Brien's statement is cited in the commentary to Article 14 of the Draft Articles on the Responsibilities of International Organisations (DARIO) as an example of the kind of situation in which international organization might be held responsible for giving aid or assistance in the commission of an internationally wrongful act. ${ }^{61}$

Researchers from Miami Law School described one of the UN raids in support of the HNP that they witnessed in the autumn of 2004:

Before and during the HNP incursion, MINUSTAH soldiers in APCs rumbled at high speeds down streets crowded with women and children. The peacekeepers were positioned with their heads and shoulders poking out of the tanks, holding automatic rifles in the ready position aimed in all directions. Each APC had one soldier manning a large, fixed gun on top. The APCs blocked off roads surrounding the target neighborhood, preventing entry or exit by journalists, investigators and anyone else who was not a police officer or soldier. Within seconds of the HNP incursion, gunfire began, and rattled sporadically for hours. When it ended, the forces cleared out... Dead bodies were on the street. One was a middle-aged woman who, residents stated, was unknown in the area but had been passing through during the attack. She was struck in the abdomen by gunfire, ran about 50 yards, and collapsed face first. ${ }^{62}$

The MINUSTAH supported HNP operations had limited success in improving security. By 2005 business leaders were complaining bitterly that MINUSTAH's role in supporting the 
HNP was not enough and MINUSTAH's own reports state that it was being asked to be more proactive in putting to stop the 'daily armed attacks against businesses' lorries and buildings, pillaging, kidnapping of employees, that put into imminent peril the survival of the country's only zone of economic activity. ${ }^{93}$ Colonel Braga explained that in response to this pressure 'MINUSTAH began to adapt to the Haitian context and to Chapter VII rules of engagement, occasionally resorting to the intense use of force against illegal armed groups and other spoilers. $^{64}$

The first major operation by MINUSTAH on Site Solèy without the HNP present took place on July $6^{\text {th }} 2005.440$ soldiers were deployed to carry out Operation Iron Fist supported by another 1000 stationed at the perimeter. ${ }^{65}$ The total count of munitions used was: 22.700 automatic firearm cartridges; 78 grenades of all models and 5 mortar shells. ${ }^{66}$ The raid began before dawn and lasted into the afternoon. MINUSTAH used armoured vehicles and shipping containers to barricade all the exits from the area. ${ }^{67}$ MINUSTAH did not bring medical units with them to assist with civilian casualties, nor did it provide transport to the hospitals, or take steps prior to the raid to ensure that the hospitals would be in a position to treat so many trauma victims. ${ }^{68}$

A cable from the US Ambassador to Haiti, James Foley, stated that '[a]s the operation was a raid, MINUSTAH did not remain in the area to do an assessment of civilian or gang member casualties' ${ }^{69}$ but because of 'the flimsy construction of homes in Cité Soleil and the large quantity of ammunition expended, it is likely that rounds penetrated many buildings, striking unintended targets. ${ }^{.70}$ Douglas Griffiths, then Deputy US Ambassador to Haiti, reported that allegations that MINUSTAH had killed twenty women and children were "credible. ${ }^{71}$ On July $29^{\text {th }}$ the Under-Secretary for Peacekeeping Operations, Jean-Marie Guehenno, admitted that: 
A number of operations have been conducted by MINUSTAH and it is not easy for MINUSTAH to conduct these operations because, operating in an urban environment, ideally you need the kind of very specialized capabilities that the mission doesn't really have. But the security situation needs to be addressed urgently...I have to be honest with you, there may have been some civilian casualties. ${ }^{72}$

The somewhat vague admission that 'there may have been some civilian casualties' suggests that at this point in time, three weeks after the raid, despite the acknowledgement that MINUSTAH did not have the 'specialized capabilities' needed for this type of operation, the UN had not yet undertaken a thorough investigation. A US Labor and Human Rights Delegation that visited Site Solèy and local hospitals twice in the three days following the raid, reported that they could find no evidence that anyone from MINUSTAH had visited the neighborhood or hospitals during those three days. ${ }^{73}$ Survivors of the raid interviewed in 2016 stated that no one from MINUSTAH has ever visited them to investigate the injuries and damage done, and never visited after any of the subsequent operations against the gangs. ${ }^{74}$

An outcry over the casualties from Operation Iron Fist, and the resignation of General Heleno, ${ }^{75}$ led to a pause in operations. But on 6 January 2006 MINUSTAH's civilian head of mission, Juan Gabriel Valdès, said that UN troops would soon 'occupy' Site Solèy: 'We are going to intervene in the coming days...I think there'll be collateral damage but we have to impose our force, there is no other way.' 76 The next day the force commander, General Bacellar, was found shot dead, reportedly from suicide; he had apparently refused to agree to the plan to 'occupy' Site Solèy because too many people would be killed. ${ }^{77}$ After Bacellar's death there was again a pause in operations against the gangs but these resumed in December 2006 with at least fourteen major raids in four months: 


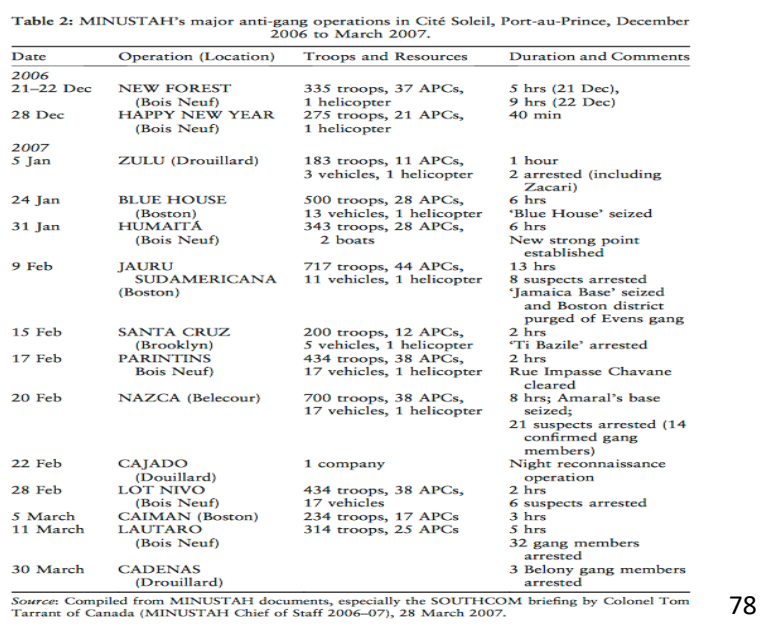

The operation on 28 December was called Happy New Year. This is not the only example of language that suggests a hostile view of the residents of poor communities in Haiti. A 2007 report by a subcommittee of the US Committee on Foreign Affairs House of Representatives, entitled UN Peacekeeping Forces: A Force Multiplier for the US? stated that MINUSTAH was eight times cheaper than keeping US troops in Haiti and that 'without the United Nations' presence...we would have witnessed an orgy of violence on that tragic island. ${ }^{79}$ Leak argues that amongst some commentators there is a tendency to use exoticizing and demonizing language when talking about Haiti. ${ }^{80}$ Pangchang records how in 2011 one NGO official when questioned as to the decision to stop distribution of free water to the camps for displaced people, responded that Haitians were 'genetically strong' as a result of the 'horrendous conditions' such as 'slavery and torture' that they had endured and therefore could live in camps where 'you or I would not survive one month. ${ }^{81}$ Ricardo Seitenfus, who was the special representative for the Organization of American States in Haiti from 2008-2010, believes that the poor communication between MINUSTAH and local residents (an inevitable consequence of the language barrier) was compounded by the fact that 'in the eyes of MINUSTAH' simply living in Site Solèy was enough to render a person 'suspicious.' 82

Dorn describes how in planning and conducting the raids into Site Solèy MINUSTAH 
'deliberately sought to draw fire from the gangs by establishing 'Strong Points' in their territories, knowing that the gangsters' pride would force them to retaliate, thus allowing the United Nations to return fire from relatively safe positions. ${ }^{, 83}$ Deliberately drawing fire in densely populated neighbourhoods creates a high risk of casualties, as MINUSTAH must have been well aware. MINUSTAH commanders and legal advisors must also have been aware of the human right implications of their operations since it was widely discussed in the press, on television and on the radio. For example, on January $9^{\text {th }} 2006$, Dr. Reginald Boulos, president of the Haitian Chamber of Commerce and Industry berated MINUSTAH on Radio Metropole saying:

we really do not care about what certain international human-rights-defense groups may say... I do not want anybody to tell me that because there is pressure at the international level, the authorities here should not fulfil their duty, that they should not do what is required of them. If they are afraid of what these international human-rights groups may say, then they do not have a place in the political leadership of MINUSTAH in this country...

You cannot make an omelette without breaking eggs. We think that MINUSTAH's generals need to make plans to limit collateral damage. But we in the private sector are ready to create a social assistance fund to help all those who would be innocent victims of a necessary and courageous action that should be carried out in Cité Soleil. ${ }^{84}$ Residents of Site Solèy, interviewed in 2016 for this research project about MINUSTAH's operations in the period 2004-2007, said that they are certain that their loved ones were shot by MINUSTAH and not gang members because they were hit by bullets fired from UN helicopters that pierced the metal rooves of their houses (the holes have since been repaired but are still visible) and the gangs do not have helicopters. ${ }^{85}$ Other said that their relatives were 
hit by 'cannon fire' from armoured vehicles and that the bullets that killed them were too large for Haitian weapons and the injuries too severe to have been made by an ordinary gun. ${ }^{86}$ Several residents said that they saw and heard MINUSTAH firing from the armored vehicles that they could see parked up behind their houses 'so many you could not see past them' and that the firing continued for several hours after the 'bandits' had left the area. ${ }^{87}$ They said that scores of houses and their entire contents were completely destroyed, saucepans 'melted into one,' and a child burned to death inside one of them. ${ }^{88}$ The residents pointed out where their houses had stood - pointing to the foundations and bits of their houses that remained. ${ }^{89}$ Their testimonies are confirmed by doctors that were working with Médecins sans Frontières (MSF) at the time ${ }^{90}$ and are also consistent with investigations conducted between 2004 and 2007 by Harvard Law School, ${ }^{91}$ Miami Law School, ${ }^{92}$ a human rights organization Haiti Lamp, ${ }^{93}$ and a US Labor and Human Rights Delegation. ${ }^{94}$

Not all the victims died immediately. The parents of a ten-year old girl shot by helicopter when she was in bed stated that their daughter died four months after she had been shot. They did not have the money to obtain the medical care she needed. Another man related that his brother (a father of four children) was shot in the eye but the local clinic was unable to remove the bullet: the brother's employer paid for his treatment in the Dominican Republic but the process of raising the money and getting him there took several months during which time the brother's health deteriorated and he was left brain damaged..$^{95}$

From the perspective of the UN, MINUSTAH's operations against the gangs are seen as successful, indeed a potential blue-print for future operations against gangs and other spoilers that violently oppose stabilization. ${ }^{96}$ Interviews with residents of Site Solèy, present a very different perspective. ${ }^{97}$ As one interviewee put it 'a massacre takes place in an area and no 
one comes to find out how many victims there were, or how many people were lost, how many cases there are. (Pause) You know what you know, it stays with you.' 98

\section{OVERVIEW OF LEGAL FRAMEWORKS}

Peacekeepers may always use force, up to an including deadly force, in self-defence of themselves and their unit or other units in the mission, and also to protect civilians from violent attacks, war crimes, genocide, and crimes against humanity, provided that the force is necessary and proportionate to the aim of protecting life. ${ }^{99}$ Whether peacekeepers may use force for other purposes depends in part on the terms of their mandate, and also on compliance with any applicable IHRL and IHL obligations.

Since 1945 use of force at the inter-state level has largely been governed by the UN Charter which 'prohibits the use of force in the relations between States, except in cases of self defence or collective security. ${ }^{100}$ Chapter VII of the Charter gives the Security Council power to authorize enforcement action in response to threats to international peace and security. For much of the twentieth century the Security Council's enforcement action powers were mainly directed against states that attacked or threatened other states. But in the 1990s UN peacekeeping missions came under severe criticism for failing to intervene to protect people from genocide and crimes against humanity in Rwanda and Bosnia-Herzegovina. Since this failure was thought to be at least partly attributable to uncertainty as to the scope of peacekeepers' authority to use force against the host state ${ }^{101}$ the Security Council responded by establishing a practice of adopting peacekeeping mandates under Chapter VII and authorizing peacekeeping missions to use 'all necessary means,' i.e. force, to carry out all or part of their mandate. 
The 'all necessary means' formula although common is not an essential component of an authorization to use force. ${ }^{102}$ Resolution 1509, establishing the UN Mission in Liberia, did not include the phrase 'all necessary means/measures' or any similar equivalent, however, the Office of Legal Affairs of the UN Secretariat advised that:

the absence of the phrase was not critical, since an authorization to use force depends upon the interpretation of the resolution, specifically, on the ordinary and natural meaning which is to be given to its terms when they are read in the context of the resolution as a whole and in the light of its object and purpose, and against the background of the discussions leading to, and the circumstances of, its adoption, in particular the report that the Secretary-General submitted pursuant to resolution 1497 (2003). ${ }^{103}$

The UN Stabilization Mission in Haiti is another example of a mission that was not mandated explicitly to use 'all necessary means' but the authority to use force was determined from the text of the resolution and associated UN documents, and was then reflected in the mission's ROE. ${ }^{104}$

The international law regimes governing use of force at the tactical level - that is against people and objects as distinct from use of force 'in the relations between states' ${ }^{105}$ - are principally IHRL, which is relevant at all times but may apply differently during hostilities, and IHL which applies only in situations that meet the legal criteria for armed conflict. The 1977 Protocol Additional to the Geneva Conventions of 12 August 1949 and relating to the Protection of Victims of Non-International Armed Conflicts distinguishes armed conflict from 'situations of internal disturbances and tensions, such as riots, isolated and sporadic acts of violence and other acts of a similar nature. ${ }^{106}$ Although there is no definition of armed conflict in the 1949 Geneva Conventions, the ICRC's 2016 commentary states that: 
the qualification of 'internal disturbances and tensions, such as riots, isolated and sporadic acts of violence and other acts of a similar nature' in Article 1 of Additional Protocol II as 'not being armed conflicts' is also considered accurate for common Article 3. ${ }^{107}$

In the view of the ILA International Law Association (ILA) committee on The Meaning of Armed Conflict in International Law, the reason that armed conflict must distinguished from internal disturbances, riots, banditry, short-lived insurrections, terrorist activities, and civil unrest ${ }^{108}$ is because in an armed conflict 'states have expanded rights to kill without warning, detain without trial, and suspend or derogate from treaties and other obligations. Individuals may have their right to life, their right to a trial, and other important rights circumscribed. ${ }^{109}$ In addition in an armed conflict 'states that provide asylum to persons fleeing the violence of armed conflict will have the duty to do so; treaty obligations may be implicated; the law of neutrality may be triggered; arms control agreements are affected.' ${ }^{110}$ Moreover 'United Nations forces engaged in armed conflict will have rights and duties not applicable in operations outside of armed conflict. ${ }^{111}$

The Appeals Chamber of the International Criminal Tribunal for the former Yugoslavia has ruled that 'an armed conflict exists whenever there is a resort to armed force between States or protracted armed violence between governmental authorities and organized armed groups or between such groups within a state.' ${ }^{112}$ The ILA report on The Meaning of Armed Conflict in International Law concludes, following a detailed analysis of treaty and customary IHL, that at a minimum, 'as a matter of customary international law, for a situation of armed violence to meet the legal criteria for armed conflict it must involve organized armed groups engaged in fighting of some intensity. ${ }^{113}$ The ICRC's Interpretive Guidance on the Notion of Direct Participation in Hostilities in International Humanitarian Law states that for an 
armed group to be classified as a party to an armed conflict it must have developed 'a sufficient degree of military organization to conduct hostilities on behalf of a party to the conflict, albeit not always with the same means, intensity and level of sophistication as state armed forces. ${ }^{, 114}$

Under the terms of the Bulletin on Observance by United Nations Forces of International Humanitarian Law promulgated by the Secretary-General in 1999, IHL will apply to peacekeepers that are 'actively engaged as combatants' in a situation of armed conflict. ${ }^{115}$ The intensity threshold for meeting this criterion is high and therefore, for most missions, even those deployed into situations of armed conflict, IHL applies only in exceptional circumstances. ${ }^{116}$ Moreover even where the intensity threshold is met and peacekeepers find themselves engaged in fierce fighting, IHL will not become applicable unless the fighting takes place in a situation of armed conflict against members of the armed forces of a party to the conflict or civilians directly participating in the conflict. This is because 'lawful use of armed force' against people that are not directly participating in an armed conflict (e.g. criminals, rioters, civilian perpetrators of war crimes) is 'a matter of law enforcement or defence of self or others' and hence is not governed by IHL. ${ }^{117}$

Although IHL is not formally applicable outside of armed conflict contexts, military forces deployed overseas in law enforcement and stabilization operations will often employ the non-offensive aspects of IHL as a matter of policy because this is the legal regime in which military forces are trained and therefore the humanitarian and civil aspects of IHL are often 'a sensible place to start in terms of adapting to local conditions. ${ }^{118}$ But the offensive aspects of IHL cannot be applied outside of an armed conflict context because IHL permits members of the armed forces of a party to a conflict to target the armed forces of the enemy, with deadly force, on the basis of their status as combatants in the conflict without regard 
to whether or not they pose an imminent threat. ${ }^{119}$ Under IHL people that do not belong to the armed forces of a party to the conflict may only be targeted if they are directly participating in hostilities and only whilst they are directly participating in hostilities. ${ }^{120}$

According to the ICRC's Interpretive Guidance on the Notion of Direct Participation in Hostilities in International Humanitarian Law, in order to for an act by a civilian to qualify as direct participation in hostilities, it must meet the following cumulative criteria:

(1) The act must be likely to adversely affect the military operations or military capacity of a party to an armed conflict or, alternatively, to inflict death, injury, or destruction on persons or objects protected against direct attack (threshold of harm), and

(2) there must be a direct causal link between the act and the harm likely to result either from that act, or from a coordinated military operation of which that act constitutes an integral part (direct causation), and

(3) the act must be specifically designed to directly cause the required threshold of harm in support of a party to the conflict and to the detriment of another (belligerent nexus). ${ }^{121}$

In the view of the ICRC even 'the perpetration of war crimes or other violations of IHL' does not constitute direct participation in hostilities. ${ }^{122}$ Such conduct may 'permit the lawful use of armed force against the perpetrators as a matter of law enforcement or defence of self or others' but '[1] oss of protection against direct attack within the meaning of IHL is not a sanction for criminal behavior.' ${ }^{123}$

It is not unusual for UN peacekeeping missions to be operating in situations that do not meet the criteria for armed conflict and to be engaged in operations designed to curb violent activity by people that are not members of an armed group that is party to an armed 
conflict, and are not civilians directly participating in an armed conflict. Peacekeeping missions often remain deployed long after the conflict in the host state that triggered their initial deployment has ended e.g. the UN Missions to Liberia (UNMIL) and Cote d'Ivoire (UNOCI) and East Timor (UNTAET). Sometimes missions are deployed to respond to situations of civil unrest that never reached the threshold of armed conflict in the first place, for example the UN Stabilization Mission in Haiti (MINUSTAH). ${ }^{124}$ Other missions may be deployed in countries where there is an armed conflict but some of the tasks that they are mandated to carry out may be unconnected with the hostilities. Examples include MINURCAT, mandated 'to take all necessary means' to inter alia 'promote and support the rapid extension of State authority' ${ }^{125}$ and the Multidimensional Integrated Stabilization Mission in Mali (MINUSMA) which is mandated to, inter alia, support the transitional authorities of Mali to extend and re-establish State administration throughout the country and support the organization and conduct of presidential and legislative elections. ${ }^{126}$ In order to carry out these kinds of tasks peacekeepers must interact with people that are not participants in an armed conflict. Some of them may be criminals with no political allegiances other than pragmatic ones. Some of them may be political activists opposed to the government or to the presence of the UN mission. Some of them, whether for pragmatic reasons or for political reasons, may forcefully seek to prevent the UN mission from achieving its goals: 'spoilers' in the nomenclature of the UN.

VIEW OF THE INTERNATIONAL COMMITTEE OF THE RED CROSS AND HUMAN RIGHTS ORGANIZATIONS - INCLUDING RELEVANT SECTORS OF THE UN The view of the ICRC, expressed in its 2015 guidance on Violence and the Use of Force, is that: 
In a peace support operation, as in any other, the legal nature of the situation in which the force is deployed determines the legal framework and rules to be respected. In this regard, the mandate, rules of engagement (setting out applicable rules, in particular for the use of force) and status of force agreements (governing the legal status of foreign troops in relation to a host nation) are only indicative. ${ }^{127}$

The ICRC guidance goes on to state that when peacekeepers use force the 'same rules then apply as for other operations depending on the situation's legal categorization.' ${ }^{128}$ The Practitioner's Guide to Human Rights Law in Armed Conflict, co-published by Chatham House Institute of International Affairs and Oxford University Press, expresses the same view. It states that although the circumstances in which a peace support operation may use force is subject to the terms of its mandate, this does not affect the applicable legal framework 'which is determined in the same manner as for all other military operations.' ${ }^{129}$ Moreover the 'terms of the Security Council resolution giving the mandate to the PSO [peace support operation], even if force is authorized, are not determinative of whether or not there is an armed conflict.' ${ }^{\text {'130 }}$

The basic principle that all human beings have a right to life is a peremptory norm and it is widely accepted that peremptory norms do bind the UN. ${ }^{131}$ The exact scope of the peremptory norm aspect of the right to life is an ongoing subject of debate but at its core is the rule that, outside of armed conflict, targeting an individual with deadly force is only permissible where there is a threat to someone's life or a threat of serious injury, and there is no other means of protecting them. ${ }^{132}$ The Bulletin on Basic Principles on the Use of Force and Firearms by Law Enforcement Officials, adopted by the UN General Assembly in 1990, prohibits use of deadly force except when it is 'strictly unavoidable in order to protect life.' ${ }^{133}$ The Bulletin also states that ' $[\mathrm{e}] \mathrm{xceptional}$ circumstances such as internal political instability or any other public 
emergency may not be invoked to justify any departure from these basic principles.' ${ }^{134}$ The former UN Special Rapporteur on extrajudicial, summary or arbitrary executions (2010-2016), Christof Heyns, asserts that the Code of Conduct for Law Enforcement Officials ${ }^{135}$ and the Basic Principles on the Use of Force and Firearms by Law Enforcement Officials 'are widely accepted as authoritative statements of the law.' ${ }^{136}$

The ICRC report on Violence and the Use of Force states that when armed forces, including peacekeepers, are engaged in a law enforcement task 'intentional lethal use of firearms may only be made when strictly unavoidable in order to protect life.' ${ }^{137}$ The majority of experts attending the ICRC's 2012 conference Use of Force in Armed Conflicts similarly concluded that, even in an armed conflict, when troops are carrying out law enforcement operations deadly force 'may be used only as last resort in order to protect life, when other available means remain ineffective or without any promise of achieving the intended result.' ${ }^{138}$

In his 2014 report as Special Rapporteur on Extrajudicial Killing, Christof Heyns reviewed the international law on the right to life relevant to use of force and concluded that under generally applicable international law, even when police or troops are acting in response to a public emergency (except when they are using force 'in the conduct of hostilities in armed conflict'), ${ }^{139}$ 'the only objective that can be legitimate when lethal force is used is to save the life of a person or to protect a person from serious injury. ${ }^{140}$ In Heyns' view, the obligation on law enforcement officers to comply with international law standards on the right to life also applies to United Nations peacekeeping troops. ${ }^{141}$ Philip Alston, who was Heyns' predecessor as Special Rapporteur shares this view. In 2005 he stated that the planning and execution of law enforcement operations by UN peacekeepers must be guided by the Basic Principles on the Use of Force and Firearms by Law Enforcement Officials' ${ }^{142}$ that and '[i]n any event, intentional 
deadly use of firearms may only be made when strictly unavoidable in order to protect life.' ${ }^{143}$ Alston reiterated this opinion in an interview in December 2016, in which acknowledged that gang violence, in particular, posed serious challengers for law enforcement officers, including peacekeepers, but stressed that nevertheless the applicable regime governing such situations is IHRL. ${ }^{144}$

The Practitioner's Guide to Human Rights Law in Armed Conflict states that 'unless the PSO is a party to an armed conflict, even situations in which violence is directed against the force, and situations in which the force takes action in self-defence, are governed by international human rights law, ${ }^{145}$ and that under IHRL the only justification for resort to deadly force by armed forces, including peacekeeping forces, 'must be a real and immediate danger to life or limb.' ${ }^{146}$ Further, the operation 'must be designed to protect life including the life of the persons presenting the threat' and any use of force must be the minimum necessary and must be 'proportionate to the aim of protecting life.' 147

\section{THE APPROACH TAKEN BY THE UN OFFICE OF LEGAL AFFAIRS}

Interviewed in June 2016, a legal advisor with many years' service in the UN Office of Legal Affairs, stated, and subsequently confirmed in writing by email, that under the United Nations current approach the mandate is the key factor that determines the circumstances in which peacekeepers can use deadly force and that:

A person that would not be a military target under traditional IHL may become an authorized military target of a UN peacekeeping operation (and therefore killed) provided that: the peacekeepers' use of force is pursuant to an authorization in a Chapter VII mandate and is provided for in the mission's rule of engagement; that the use of force is proportionate to 
achieving the authorized objective; that minimum force is used; and that force is used only as a last resort. This framework applies across the board to all UN peacekeeping missions, regardless of whether the situation is one of armed conflict or not. ${ }^{148}$

However, she stressed that whilst the summary above 'fully captures our discussion:' The only amplification is that while the authority to use force comes from the Security Council based on the specific mandate and the Chapter VII authority to use 'all necessary means' as reflected in the mission-specific ROE - not from IHL except where the mission becomes a party to the conflict or from IHRL - the customary principles of both IHL and IHRL are nonetheless integral to the conduct of the mission including its military component. ${ }^{149}$

In a separate interview another senior advisor in the UN Office of Legal Affairs explained the United Nations doctrine in very similar terms. ${ }^{150}$ The views stated above were expressed in the context of interviews and therefore have not gone through the rigorous process of analysis and checks for detail, nuances, and unintended implications, that would have to be done before producing a public bulletin; and therefore they cannot be treated as authoritative. ${ }^{151}$ Nevertheless the core of the argument is an accurate reflection of the stance taken by the UN Office of Legal Affairs: the two Legal Officers' had the same view on the legal rules governing use of force by UN peacekeepers and this view was also confirmed by Legal Officers and Military Advisors attending a follow-up seminar meeting on the issue. ${ }^{1}$ There was a clear consensus at that meeting (which was attended by approximately twenty people) that the content of the United Nations doctrine on use of force is as described above.

Although 'the customary principles of both IHL and IHRL are ...integral to the conduct' of UN peacekeeping missions it is difficult to see how customary IHRL obligations regarding the right to life can be properly applied and upheld if the UN does not explicitly affirm that 
peacekeepers must adhere to IHRL standards on the right to life in all law enforcement operations $^{152}$ and does not require missions to distinguish between use of deadly force against combatants and use of deadly force against criminals, rioters and other 'spoilers.' The Chatham House Practitioners' Guide to Human Rights Law in Armed Conflict states that when carrying out law enforcement operations, as distinct from hostilities operations, any use of deadly force by armed forces, including peacekeepers, 'must be proportionate to the aim of protecting life.' 153 This contrasts with the UN formulation of proportionality as stated on its own website:

A UN peacekeeping operation should only use force as a measure of last resort. It should always be calibrated in a precise, proportional and appropriate manner, within the principle of the minimum force necessary to achieve the desired effect, while sustaining consent for the mission and its mandate. ${ }^{154}$

A UN Master List of Rules of Engagement and Sample ROE were set out in the UN Guidelines for the Development of Rules of Engagement, approved in 2000 by Jean-Marie Guehenno, then Secretary-General for Peacekeeping Operations. The Guidelines set out the procedure and basic legal framework for drafting ROE. ${ }^{155}$ The principles of minimum force and proportionality as set out in these guidelines and standardly in UN ROE for peacekeeping missions, require that:

Any force used must be limited, in its intensity and duration, to that which is necessary to achieve the authorized objective. In some circumstances, operational urgency may dictate that immediate use of deadly force may be necessary for this purpose.

The use of force must be commensurate with the level of the threat. However, the level of force that is used may have to be higher than the level of the threat in order to avoid or minimise UN or civilian casualties, or, in the case of offensive action, to ensure that the authorized 
objective is achieved.

Commanders should, where appropriate, consider the use of alternatives to the use of physical force, such as deception, psychological methods, negotiation, and other non-lethal means, including the deployment or manoeuvre of larger forces in order to demonstrate resolve. ${ }^{156}$

This is a very different standard of proportionality to the IHRL standard which requires use of deadly force to be proportionate to the aim of protecting life. Given the very broad mandates, and routine authorization to use 'all necessary means' that characterise modern peacekeeping, this is a critical difference that has significant implications for host state communities living in the vicinity of UN operations.

\section{UN Rules of Engagement for Peacekeeping Missions}

The Sample ROE were set out in the UN Guidelines for the Development of Rules of Engagement, approved in 2000 by Jean-Marie Guehenno, consists of eleven suggested rules:

Rule 1.1 Use of force, up to, and including deadly force, to defend oneself and other UN personnel against a hostile act or a hostile intent is authorized.

Rule 1.2 Use of force, up to, and including deadly force, to defend other international personnel against a hostile act or a hostile intent is authorised.

Rule 1.3 Use of force, up to, and including deadly force, to resist attempts to abduct or detain oneself and other UN personnel is authorised.

Rule 1.4 Use of force, up to, and including deadly force, to resist attempts to abduct or detain other international personnel is authorised.

Rule 1.5 Use of force, up to, and including deadly force, to protect United Nations' 
installations, areas or goods, designated by the Head of Mission in consultation with the Force Commander, against a hostile act, is authorised.

Rule 1.6 Use of force, up to and including deadly force, to protect key installations, areas or goods designated by the Head of Mission in consultation with the Force Commander, against a hostile act is authorised.

\section{OR}

Rule 1.7 Use of force, up to but excluding deadly force, to protect key installations, areas or goods designated by the Head of Mission in consultation with the Force Commander, against a hostile act is authorised.

Rule 1.8 Use of force, up to and including deadly force, to defend any person who is in need of protection against a hostile act or hostile intent, when competent local authorities are not in a position to render immediate assistance is authorized. When and where possible, permission to use force should be sought from the immediate superior.

Rule 1.9 Use of force, to prevent the escape of any apprehended or detained person, pending hand-over to appropriate civilian authorities, is authorized. In case of necessity to act in self-defence use of force, up to and including deadly force, is authorized.

Rule 1.10 Use of force, up to, and including deadly force, against any individual and/or party who limits or intends to limit freedom of movement, is authorised. ${ }^{157}$

Rule 1.11 Use of force, up to, and including deadly force, to resist armed forceful attempts to prevent peacekeepers from discharging their duties is authorized. ${ }^{158}$

These Guidelines and Sample ROE are provided to Troop Contributing States for use in training of their troops. They provide a template for drafting mission specific ROE but they do not restrict expansion beyond the suggestions in the template if the drafters of the ROE believe 
that the mandate requires it.

Troop contributing states may, and often do, introduce caveats narrowing the ROE as applied to their troop contribution - usually in order to comply with their own domestic laws or to avoid becoming drawn into an armed conflict. Commander Dale Stephens, writing about his experiences whilst serving with the UN Transitional Administration in East Timor (UNTAET), commented that the 'UNTAET ROE were expressed broadly and, prima facie, did permit the use of force in order to perform necessary duties, though this was necessarily 'read down' to permit lethal force only in situations where lives were directly threatened.' ${ }^{159}$ UNTAET's numbered ROE on use of force, ${ }^{160}$ which Commander Stephens considered to have been 'expressed broadly,' were almost identical to those set out in the Sample UN Rules of Engagement annexed to the UN Guidelines for the Development of Rules of Engagement 2000. In the intervening six years, ROE have diverged significantly from the UN sample rules approved by Guehenno in 2000 and are much broader than the UNTAET ROE that Commander Stephens thought were 'expressed broadly' and therefore needed to be read down.

As an illustration of the kind of potential problems arising from robust mandates and the lack of clarity as to the applicable law governing use of force by peacekeepers, it is worth looking at a draft for a Soldiers' Blue Card drawn up for troops serving with the United Nations Multidimensional Integrated Stabilization Mission in the Central African Republic (MINUSCA). Soldier's Cards are issued to individual troop members to serve as a guide and are intended to be short and clear enough to be understood by soldiers of all ranks and experiences. A draft version of the Blue Card for MINUSCA, dated August 2014, authorizes the soldier to use force 'up to and including deadly force' in a number of listed circumstances including to:

support the Transitional Authorities in the rapid extension of State authority 
and

to support urgent temporary measures adopted by MINUSCA in line with its mandate to maintain basic law and order and fight impunity. ${ }^{161}$

There is no equivalent to these rules in Guehenno's Sample ROE. Both rules appear to relate to law enforcement tasks, especially the second one authorizing use of deadly force 'to maintain basic law and order.' These seemingly broad authorizations to use deadly force are qualified by an instruction set out in a separate section of the Blue Card entitled Firing Rules, which states that 'If you have to open fire:'

Use deadly force to protect UN personnel and civilians only when there is a grave threat to life or threat of abduction, detention or serious bodily injury and when other means, including non-deadly force, do not hold out any promise of removing that threat. ${ }^{162}$

The main text of MINUSCA's draft ROE contains all the rules set out on the Blue Card but also states that:

[e]verything feasible must be done to verify that the objectives to be attacked are neither civilians nor civilian objects, but are military objectives within the meaning of these terms under the law of armed conflict. ${ }^{163}$

MINUSCA'S rules limiting deadly force to situations where there is a grave threat to life, abduction or detention, and requiring compliance with the principle of distinction appear to be incompatible, prima facie, with the rules in the Numbered ROE for MINUSCA and the Soldier's Blue Card authorizing use of force, up to and including deadly force, to carry out law enforcement tasks. Presumably this apparent incompatibility was clarified in training - or in revisions to the documents before the ROE and Soldier's Card were issued. ${ }^{164}$ But the fact that authorizations for use of deadly force that are so complex as to require clarification suggests that 
even within the $\mathrm{UN}$ there is a lack of consensus as to the circumstances in which deadly force may be used to carry out law enforcement tasks. There is no reference to IHRL in either the main text of the ROE or the Blue Card despite the fact that the draft ROE explicitly authorize use of deadly force 'to maintain basic law and order.'

The most plausible explanation for including numbered ROE authorizing use of deadly force to 'promote and support the rapid extension of State authority' and 'to support urgent temporary measures adopted by MINUSCA in line with its mandate to maintain basic law and order and fight impunity' is the need to ensure that ROE cover all situations for which troops have a mandate to act. Security Council Resolution 2149 authorizes MINUSCA 'to take all necessary means to carry out its mandate, within its capabilities and its areas of deployment' and authorizes it inter alia to 'promote and support the rapid extension of State authority' and to 'adopt urgent temporary measures on an exceptional basis and without creating a precedent and without prejudice to the agreed principles of peacekeeping operations... to maintain basic law and order and fight impunity. ${ }^{165}$

The relationship between the mandating resolution and ROE is not always as direct as in the MINUSCA example above. The ROE templates set out in the UN Master Lists of 2000 and 2002 contain no rule for use of deadly force in response to civil unrest. However MINUSTAH's ROE explicitly authorizes the mission to use force, 'up to and including deadly force in order to put a stop to acts of civil unrest. ${ }^{166}$ MINUSTAH's mandate does not refer to civil unrest: it does state that the mission is mandated 'in support of the Transitional Government, to ensure a secure and stable environment within which the constitutional and political process in Haiti can take place. ${ }^{167}$ This provision is the first one in the list of mandated tasks - which suggests that the Council considered this to be one of the primary tasks of the mission. Presumably it is this 
provision that provides the basis for the authorization in MINUSTAH's ROE to use deadly force in response to civil unrest. ${ }^{168}$

The provision in MINUSTAH's ROE for dealing with civil unrest contrasts with a similar provision in the ROE drawn up in 2009 for use by the UN Mission in the Central African Republic (MINURCAT), which authorized use of force, 'up to and including deadly force to prevent or put a stop to acts of civil unrest that are a threat to life or of serious bodily injury. ${ }^{\prime} 169$ Civil unrest is defined in both MINUSTAH's and MINURCAT's ROE as 'the commission, perpetration, or instigation of acts of violence that effect public peace and order.' ${ }^{170}$ MINURCAT's ROE on civil unrest is in line with human rights law standards but arguably that for MINUSTAH is not. Neither sets of ROE make any reference whatsoever to IHRL.

It is not just the numbered ROE setting out the circumstances in which deadly force may be used, that are of concern. The sections in mission ROE dealing with permissible Weapon States also raise questions with regard to compatibility with IHRL. For example, under MINUSTAH's ROE the Force Commander may authorize 'as he believes operationally appropriate,' without need for consultation with UN headquarters, that:

Helicopter-mounted guns and missiles may be deployed. Guns may have a loaded magazine or belted ammunition inserted in or attached to the weapon. They may be cocked and ammunition inserted into the breach and fired. Missiles may be prepared for immediate firing. ${ }^{171}$

Given that MINUSTAH's mandating resolution and relevant Secretary-General's reports confirmed that the main problem in Haiti was not armed conflict but 'the existence of challenges to the political, social and economic stability of Haiti' - and that the main source of armed violence were the gangs based in Site Solèy and similarly impoverished densely populated neighbourhoods - an authorization to use helicopter mounted guns and missiles without the need 
for further consultation or higher authorization, seems extraordinary.

\section{CONCLUSION}

The United Nations Human Rights Up Front initiative, adopted in 2014, commits the UN to entrenching human rights norms into all aspects of its missions. Although it 'is designed primarily for settings where the UN does not have a political or peacekeeping mission' the Secretary-General's 2014 Aide Memoire to the plan states that 'its spirit can and should also be applied to "mission settings." ${ }^{172}$ The High-level Independent Panel on Peace Operations has recommended that the 'entire United Nations system commits to the full implementation of the Human Rights Up Front initiative.' ${ }^{173}$

IHRL requires that any operation using deadly force, outside of a hostilities operation 'must be designed to protect life including the life of the persons presenting the threat' and any use of force must be the minimum necessary to protect life and must be 'proportionate to the aim of protecting life. ${ }^{174}$ Because there is no reference to IHRL standards on use of force in UN ROE it is left up to troop contributing states to ensure compliance with them, for example through the adoption of caveats or through a process of 'reading down' authorizations to a level that complies with their domestic laws. The likely consequence is that some troop contributing states will apply an IHRL standard but others will not.

The UN Secretariat should draft a formal Bulletin setting out the IHRL obligations of UN peacekeepers with regard to use of deadly force against persons that are not parties to an armed conflict. ROE should clearly distinguish between hostilities operations and law enforcement operations and make clear that outside of hostilities use of deadly force may only be used to protect life and its use must be proportionate to the aim of protecting life. The 
UN should also ensure that, when it deploys a mission with a mandate to use force in a broad range of circumstances, the mission is equipped with the personnel and resources to ensure that civilians affected by its operations receive appropriate post-operation care and support, including medical care that is of a standard commensurate with the status, principles and ideals of the UN. 175

An independent inquiry should be undertaken into the deaths, injuries and destruction to homes that occurred as result of UN peacekeeping operations in Haiti in the period 2004-2007. There is strong evidence from testimonials, photographs and film footage; from the kind of injuries inflicted; from bullet holes in the roofs of some houses and the total levelling of other houses; from the bullets collected (many of which are marked as made in Brazil and are too large to be from an ordinary weapon) - that MINUSTAH fired from heavy fixed guns mounted on armoured vehicles and fired from helicopters. The UN itself has recognized that 'there may have been some civilian casualties' ${ }^{\text {176 }}$ as a result of MINUSTAH's use of force on July $6^{\text {th }} 2005$ given the scale of the operation and the fact that the neighborhood is densely populated and many people live in thin corrugated metal houses. There were at least fourteen other major raids in the period 2004-2007 in which casualties are likely to have occurred for the same reasons. This warrants an investigation, established with the authority of the UN, but carried out by a highly qualified international investigative team that is independent of any person or organization that has been involved in the mission. 
Endnotes

* Siobhán Wills

${ }^{1}$ Bulletin on Observance by United Nations Forces of International Humanitarian Law, (1999) UN Doc ST/SGB/1999/13

${ }^{2}$ S/RES 154230 April 2004

${ }^{3}$ Ibid

${ }^{4}$ Report of the Secretary-General on Haiti/2004/300, 16 April 2004 paragraph 23

${ }^{5}$ A Sotomeyer The Myth of the Democratic Peacekeeper: Civil-Military Relations and the United Nations, (John Hopkins University Press 2014), page 141; Cable U.S. Embassy Chargé d'Affaires 01/06/2006 http://www.ijdh.org/author/admin/page/93/

${ }^{6}$ Civil and Political Rights including the Question of Disappearances and Summary Executions, Report of the Special Rapporteur, Philip Alston E/CN.4/2006/53/Add.1 27 March 2006, pages 324-325.

${ }^{7}$ Ibid

8 "Haiti Post-Dread Wilme: MINUSTAH Takes off the Pressure." Cable Number Port au Prince 001829 from US Embassy Port au Prince to US State Department Headquarters, K Yearman, The Cité Soleil Massacre Declassification Project https://www.cod.edu/people/faculty/yearman/cite soleil.htm; A Summary of Findings of the US Labor and Human Rights Delegation to Haiti, S Donnelly, 12 July 2005

http://www.margueritelaurent.com/campaigns/campaignone/human_rights_reports/unmassacre.h tml; K Pina Haiti: We Must Kill the Bandits (documentary with footage taken by local journalists) https://www.youtube.com/watch?v=25Mf7Lv5Q08

9 'Clarification on the joint PNH/MINUSTAH operation in Cité Soleil Port-au-Prince' UN statement by Direction Centrale de la Police Judiciaire (DCPJ) at 250-3630 and MINUSTAH ( $\mathrm{Je}$ Wè Bouch Pale) at 244-3503 dated December 26, 2006

http://www.ijdh.org/2006/12/archive/institute-for-justice-democracy-in-haiti-home-437/

${ }^{10}$ W Pierre and J Sprague, 'Haiti: Poor Residents of Capital Describe a State of Siege' Inter Press Service February 282007 http://www.ipsnews.net/2007/02/haiti-poor-residents-of-capitaldescribe-a-state-of-siege/; The Cité Soleil Massacre Declassification Project (n 8); UN in Haiti 
accused of second massacre http://haitiaction.net/News/HIP/1_21 7/1 21 7.html; ML Mendonça, 'UN Troops Accused of Human Rights Violations in Haiti' Americas Program, Center for International Policy (CIP), January 21, 2008; BF Duramy, Gender and Violence in Haiti: Women's Path from Victims to Agents (Rutgers University Press 2014), page 28; Interviews with residents of Bwa Nef, Site Solèy, and Professors Ilionor Louis and Camille Chalmers, State University of Haiti, April and October 2016 for documentary film 'It Stay With You: Use of Deadly Force by UN Peacekeepers in Haiti' premiere Port-au-Prince, June 2016 funded by the Arts and Humanities Research Council, UK, based on research funded by the British Academy

${ }^{11}$ United Nations Juridical Yearbook 2009 (New York 2010) page 429; R Fatton Jr, 'Haiti's Crisis of Governance' in J Heine, A Stewart Thompson, Fixing Haiti and Beyond (United Nations University 2011), page 41 at 61; C Lynch, U.N. Peacekeeping More Assertive, Creating Risk for Civilians, Washington Post, 15 August 2005

12 Protocol I additional to the Geneva Conventions, 8 June 1977, Article 51 (1)(b)

${ }^{13}$ Basic Principles on the Use of Force and Firearms by Law Enforcement Officials; Adopted by the Eighth United Nations Congress on the Prevention of Crime and the Treatment of Offenders, Cuba, 1990. United Nations General Assembly resolution 45/111 adopted without a vote the same year welcomed the Basic Principles, paragraph 9.

${ }^{14}$ British-Academy Mid-Career Fellowship 2015-2016 to research use of deadly force by peacekeepers and UN rules of engagement for law enforcement activities. Arts and Humanities Research Council Innovation Award 2016-2017 to make a documentary film 'It Stays with You: Use of Deadly Force by Peacekeepers in Haiti' working with survivors of UN raids in Site Solèy, using participatory practices: the film premieres in June 2016.

${ }^{15}$ International Law Association study-group 'The conduct of hostilities under international humanitarian law - challenges of 21 st century warfare' Interim Report 2014, http://www.ilahq.org/en/committees/study groups.cfm/cid/1040; ICRC, Violence and the Use of Force, January $1^{\text {st }} 2015$ https://www.icrc.org/en/publication/0943-violence-and-use-force; ICRC, Use of Force in Law Enforcement Operations, September $3^{\text {rd }} 2015$; ICRC Expert Meeting Report, The Use of Force in Armed Conflicts: Interplay between the Conduct of Hostilities and Law Enforcement Paradigms November 2013, http://www.icrc.org/eng/assets/files/publications/icrc002-4171.pdf; D Murray, D Akande, F Hampson, C Garraway, N Lubell, E Wilmhurst, Practitioner's Guide to Human Rights Law in Armed Conflict (Chatham House Royal Institute of International Affairs and Oxford University Press 2016)

${ }^{16}$ Basic Principles on the Use of Force and Firearms by Law Enforcement Officials (n 13)

${ }^{17}$ Civil and Political Rights including the Question of Disappearances and Summary Executions, Report of the Special Rapporteur, Philip Alston E/CN.4/2006/53/Add.1 27 March 2006, page 323; Report of the Special Rapporteur on extrajudicial, summary or arbitrary executions, Christof Heyns A/HRC/26/36 1 April 2014; paragraph 58, 75 and 145 
${ }^{18}$ ICRC, Violence and the Use of Force, (n 15); ICRC Advisory Service on International Humanitarian Law, Use of Force in Law Enforcement Operations, (n 15)

${ }^{19}$ Final Report on the Meaning of Armed Conflict in International Law, ILA Committee on Use of Force, Hague Conference, 2010, page 4

${ }^{20}$ ICRC Expert Meeting Report, The Use of Force in Armed Conflicts: Interplay between the Conduct of Hostilities and Law Enforcement Paradigms November 2013; D Murray, D Akande, F Hampson, C Garraway, N Lubell, E Wilmhurst, Practitioner's Guide to Human Rights Law in Armed Conflict (n 15) page 263

${ }^{21}$ Interviews with Senior Officers in the UN Office of Legal Affairs, June 2016 and a seminar discussion also in June 2016 with legal advisors, civilian and military personnel, to current UN peacekeeping missions, some based at UN Headquarters and others working in the field.

${ }^{22} \mathrm{UN}$ Guidelines for the Development of Rules of Engagement and ROE for UN Peacekeeping Operations, Jean-Marie Guehenno, December $1^{\text {st }} 2000$

${ }^{23}$ For example the rule authorizing MINUSTAH to use force, 'up to and including deadly force in order to put a stop to acts of civil unrest' defined as 'the commission, perpetration, or instigation of acts of violence that effect public peace and order' in Rules of Engagement for the Military Component of the United Nations Stabilization Mission in Haiti, 28 June 2004, signed by Jean-Marie Guehenno, Under-Secretary General for Peacekeeping Operations (confidentially on file with author).

${ }^{24}$ E.g. the rule in the UN Guidelines for the Development of Rules of Engagement and ROE for UN Peacekeeping Operations, Jean-Marie Guehenno, December $1^{\text {st }} 2000$, stating that 'Use of force, up to and including deadly force, to protect key installations, areas or goods designated by the Head of Mission in consultation with the Force Commander, against a hostile act is authorised.'

${ }^{25}$ E Paddon Rhoads, Taking Sides in Peacekeeping: Impartiality and the Future of the United Nations, (Oxford University Press 2016) page 71

${ }^{26}$ S/RES 222625 June 2015, paragraph 19 c

${ }^{27}$ S/RES 2149 April 2014, paragraphs 30 (a) (iv) and 40

${ }^{28}$ O Engdahl, 'The Status of Peace Operation Personnel under International Humanitarian Law, Yearbook of International Humanitarian Law, (December 2008) Vol. 11, 109, at page 113

${ }^{29}$ www.un.org/en/sc/inc/pages/pdf/mandate.xls

${ }^{30}$ Ibid 
${ }^{31}$ Ibid; In some missions Chapter VII authority is attached to certain parts of the mandate onlyfor example in Security Council resolution 1542 of 30 April 2004, mandating the UN peacekeeping mission in Haiti, only the first part 'Secure and Stable Environment' is mandated under Chapter VII, parts two and three on 'Political Process' and 'Human Rights' fall outside the Chapter VII authority. In addition to the reference to Chapter VII mandating resolutions commonly authorize the mission 'to take all necessary means to carry out its mandate within its capabilities and areas of deployment' or similar language sometimes specifying sections to which this authorization applies e.g. Security Council resolution 2100 of 25 April 2013 authorizes the UN Multi-Dimensional Integrated Stabilization Mission in Mali (MINUSMA) to use 'all necessary means within its capabilities and areas of deployment' to carry out certain of its mandated tasks - the tasks specified as being within the 'all necessary means' authorization include law enforcement activities such as to 'support the transitional authorities of Mali to extend and re-establish State administration throughout the country.'

${ }^{32}$ Y Dinstein, The Right to Humanitarian Assistance' Naval War College Review (2000) Vol. 53, 4, 78, at page 87; N Blokker, 'Ch. 9 Outsourcing the Use of Force: Towards More Security Council Control of Authorized Operations?' in The Oxford Handbook of the Use of Force in International Law, ed. M Weller, (Oxford University Press, 2015) page 210

${ }^{33}$ Draft DPKO/DFS Concept Note on Robust Peacekeeping? (2010), section 1

${ }^{34}$ E Paddon Rhoads, Taking Sides in Peacekeeping: Impartiality and the Future of the United Nations, (n 25), page 38 The book is a development of her DPhil, which was supervised by Professor Sir Adam Roberts; A report by the International Peace Institute, notes that many peacekeeping missions 'now have mandates to combat organized and serious crime, although the resources and expertise to deal with the threat are still limited:' M Shaw and W Kemp, Spotting the Spoilers: A Guide to Analyzing Organized Crime in Fragile States, (International Peace Institute, 2012), page 5

${ }^{35} \mathrm{~J}$ Karlsrud, 'The UN at war: examining the consequences of peace-enforcement mandates for the UN peacekeeping operations in the CAR, the DRC and Mali,' Third World Quarterly 36: 1 (2015), page 42

${ }^{36}$ A Bellamy and C Hunt, 'Twenty-first century UN peace operations: protection, force and the changing security environment' International Affairs 91: 6 (2015) 1277, page 1282

${ }^{37}$ Ibid, page 1283

${ }^{38}$ MONUSCO (DRC), MINUSCA (CAR), MINUSMA (Mali) and MINUSTAH (Haiti).

${ }^{39}$ S/RES 170111 August 2006, paragraph 12

${ }^{40}$ S/RES 222625 June 2015, paragraph 19 c

${ }^{41} \mathrm{http}$ //www.un.org/en/peacekeeping/operations/pkmandates.shtml 
42 Joint Doctrine Note 5/11 Peacekeeping: An Evolving Role for Military Forces, July 2011 (The Development, Concepts and Doctrine Centre, UK Ministry of Defence, Shrivenham) paragraph 210. Joint Doctrine Note 5/11 is now superseded by Allied Joint Doctrine for the Military Contribution to Peace Support, AJP-3.4.1 (NSO December 2014) which states at paragraph 0119, that a peacekeeping force 'should be prepared to use force to implement the mandate.'

${ }^{43}$ United Nations. Peacekeeping Operations Principles and Guidelines (United Nations, 2008) page 34

${ }^{44}$ Draft DPKO/DFS Concept Note on Robust Peacekeeping? (2010), section 3

${ }^{45} \mathrm{C}$ Call and G Sorensen, U.N. Operations and State-building: A Case Study of Haiti, Center on International Cooperation, May 2009, page 5. In researching the case study Call and Sorenson conducted interviews in Haiti and at UN headquarters with various units at DPKO, DPA, UNDOCO and UNDP, as well as with think-tanks and some experts, which suggests that their view reflects a degree of consensus at the UN. Their case study is cited in the UN DPKO's own reports eg Second Generation Disarmament, Demobilization, and Reintegration Practices in UN Peacekeeping Operations (UN DPKO, Office of Rule of Law and Security Institutions 2010) page 67

\section{http://www.un.org/en/peacekeeping/documents/2GDDR ENG WITH COVER.pdf}

46 'Towards a Post-MINUSTAH Haiti: Making an Effective Transition: Latin America/Caribbean Report N44,' International Crisis Group, 2 August 2012, page 16; M Schuberth, 'A transformation from political to criminal violence? Politics, organised crime and the shifting functions of Haiti's urban armed groups,'(2015) Conflict, Security \& Development, $15: 2,169$, at page 176 ;

I. $\quad{ }^{47}$ ICRC, Haiti bulletin - 26 February 2004, https://www.icrc.org/eng/resources/documents/misc/5wjlkb.htm

${ }^{48}$ A Serafin, 'Urban Violence: War by any other name' Magazine of the International Red Cross and Red Crescent Movement, Volume 1 (2010), www.redcross.int/EN/mag/magazine2010_1/2023.html

${ }^{49} \mathrm{C}$ Call and G Sorensen, U.N. Operations and State-building: A Case Study of Haiti (n 45) page 5 .

${ }^{50}$ Second Generation Disarmament, Demobilization, and Reintegration Practices in UN Peacekeeping Operations (UN DPKO, Office of Rule of Law and Security Institutions 2010) page 67

\section{http://www.un.org/en/peacekeeping/documents/2GDDR_ENG_WITH_COVER.pdf}

${ }^{51} \mathrm{C}$ Braga, Between absolute war and absolute peacekeeping: searching for a theory of the use of force on behalf of the international community, Doctoral Thesis, Instituto de Relações 
Internacionais do Centro de Ciências Sociais da PUC-Rio, March 2015, page 182

${ }^{52} \mathrm{~S} / 2005 / 12425$ February 2005, paragraph 58

${ }^{53}$ Report of the Security Council mission to Haiti, 13 to 16 April 2005

S/2005/302 6 May 2005, paragraph 24

${ }^{54}$ R Lindsay 'Play for Peace' Soccer Match Turns Into Massacre' August 28 2005, Institute for Justice and Democracy in Haiti http://www.ijdh.org/2005/08/archive/institute-for-justicedemocracy-in-haiti-home-91/

${ }^{55}$ L Hermantin, 'Alleged attacks by police, gangs investigated in Haiti,' Miami Herald, 1 September 2005, http://faculty.webster.edu/corbetre/haiti-archive-new/msg26490.html

56 Ibid

57 "Haiti: Amnesty International calls on the transitional government to set up an independent commission of enquiry into summary executions attributed to members of the Haitian National Police," November 11, 2005, available at www.amnesty.org

58 Annex to 'Identical Letters Dated 25 February 2013 from the Secretary-General Addressed to the President of the General Assembly and to the President of the Security Council' (5 March 2013), UN Doc. A/67/775-S/2013/110.

${ }^{59}$ Ibid, paragraph 27

${ }^{60}$ P O'Brien, Note of 12 October 2009 to A Le Roy, cited in V Lanovoy, 'Complicity in an Internationally Wrongful Act' SHARES project research paper 38 (2014), 19, www.sharesproject.nl

${ }^{61}$ Draft articles on the responsibility of international organizations, with Commentaries, Adopted by the International Law Commission at its sixty-third session, in 2011, and submitted to the General Assembly as a part of the Commission's report covering the work of that session (A/66/10), commentary to article 14

${ }^{62}$ T. M. Griffin and I.P. Stotsky Center for the Study of Human Rights, University of Miami, Haiti Human Rights Investigation, November 11-21, page 44

${ }^{63}$ Civil and Political Rights including the Question of Disappearances and Summary Executions, Report of the Special Rapporteur, Philip Alston E/CN.4/2006/53/Add.1 27 March 2006, page 326 (translated from French)

${ }^{64}$ CC Vianna Braga 'MINUSTAH and the Security Environment in Haiti: Brazil and South American Cooperation in the Field,' (2010) International Peacekeeping Vol. 17, Issue 5, page 711 , at 716 
65 "Haiti Post-Dread Wilme: MINUSTAH Takes off the Pressure." Cable from US Embassy Port au Prince to State Department Headquarters. Cable Number: Port au Prince 001829 July 12, 2005, K Yearman, The Cité Soleil Massacre Declassification Project (n 9)

${ }^{66}$ Extrajudicial, summary or arbitrary executions: Report of the Special Rapporteur, Philip Alston, E/CN.4/2006/53/Add.1 27 March 2006, page

${ }^{67}$ Interviews with residents of Site Solèy April and November 2016 (n 10); S Donnelly, Eyewitnesses Describe Massacre by UN Troops in Haitian Slum, Democracy Now, 11 July 2005 , http://www.democracynow.org/2005/7/11/eyewitnesses_describe_massacre_by_un troops; K Pina Haiti: We Must Kill the Bandits (documentary with footage taken by local journalists) https://www.youtube.com/watch?v=25Mf7Lv5Qo8

68 Ibid

69 "Human Rights Groups Dispute Civilian Casualty Numbers from July 6 MINUSTAH Raid." Cable from US Embassy Port au Prince to State Department Headquarters. July 26, 2005, at K Yearman, The Cité Soleil Massacre Declassification Project (n 8)

${ }^{70}$ Extrajudicial, summary or arbitrary executions: Report of the Special Rapporteur, Philip Alston, E/CN.4/2006/53/Add.1 27 March 2006, page 325

71 "Haiti Post-Dread Wilme: MINUSTAH Takes off the Pressure." Cable Number: Port au Prince 001829 July 12, 2005 from US Embassy Port au Prince to State Department Headquarters available from K Yearman, The Cité Soleil Massacre Declassification Project (n 8)

${ }^{72}$ UN HAITI/GUENNO 28 July 2005

http://www.unmultimedia.org/avlibrary/asset/U050/U050729b/

${ }^{73}$ A Summary of Findings of the US Labor and Human Rights Delegation to Haiti, S Donnelly, 12 July 2005 (n 8)

${ }^{74}$ Interviews with residents of Bwa Nef, Site Solèy April and November 2016 (n 10)

${ }^{75}$ General Heleno told a congressional commission in Brazil that the mission was 'under extreme pressure from the international community to use violence': Operation Deep Pockets, The Economist December 16 ${ }^{\text {th }} 2004$ http://www.economist.com/node/3503743; K Knodell 'American Troops Take On The Violent Work of Peacekeeping South,' Offiziere.ch, 28 July 2014, http:/www.css.ethz.ch/en/services/digital-library/articles/article.html/182187/pdf

${ }^{76}$ C Lynch, U.N. Peacekeeping More Assertive, Creating Risk for Civilians, Washington Post, 15 August 2005

${ }^{77}$ K Ives, 'WikiLeaks points to US meddling in Haiti,' The Guardian, 21 January 2011; AM Brambilla, 'Mystery Surrounds Death of UN Official in Haiti' 
http://english.ohmynews.com/articelview/article_view.asp?menu+c10400\&no=268037\&rel_no= 1 ;

${ }^{78}$ Walter Dorn, who was working for the intelligence sector of the UN at the time, published this table: W Dorn, 'Intelligence-led Peacekeeping: The United Nations Stabilization Mission in Haiti (MINUSTAH), 2006-07' Intelligence and National Security, Volume 24, No. 6 December 2009 , page 805 , at 818

${ }^{79}$ UN Peacekeeping Forces: A Force Multiplier for the US? Subcommittee on International Organizations, Human Rights \& Oversight before US Committee on Foreign Affairs House of Representatives, June 2007, Serial No 110-61 http://www.foreignaffairs.house.gov

${ }^{80}$ A Leak in 'A Vain Fascination' Bulletin of Latin American Research, Vol. 32, No. 4, pages 394-406

${ }^{81}$ D Pangchang '"Waiting for Helicopters: Perceptions, Misperceptions and the Right to Water in Haiti' in M Sculler and P Morales, Tectonic Shifts (2012) page 185

${ }^{82}$ Interview with Ricardo Seitenfus, Port-au-Prince, November 2016

${ }^{83}$ W Dorn, 'Intelligence-led Peacekeeping: The United Nations Stabilization Mission in Haiti (MINUSTAH), 2006-07' (n 78), page 814

${ }^{84}$ Dr. Reginald Boulos, president of the chamber of commerce, on Radio Metropole, January 9 2006, 'All Sectors Stay Home on January $9^{\text {th' }}$ calling for a strike to demand that MINUSTAH take stronger action against the gangs: http://haitipolicy.org/2006/01/all-sectors-stay-home-onjanuary-9-to-honor-the-memory-of-the-victims

${ }^{85}$ Interviews with residents of Bwa Nef, Site Solèy April and November 2016 (n 10)

${ }^{86}$ Ibid

${ }^{87}$ Ibid

${ }^{88}$ Ibid

${ }^{89}$ Ibid

${ }^{90}$ Interview with John Caroll, a doctor at St Catherine's Hospital, Site Solèy, April 2016

${ }^{91}$ Keeping the Peace in Haiti? An Assessment of the United Nations Stabilization Mission in Haiti Using Compliance with its Prescribed Mandate as a Barometer for Success Harvard Law Student Advocates for Human Rights, Cambridge, Massachusetts \& Centro de Justiça Global, Rio de Janeiro and São Paulo, Brazil, March 2005

${ }^{92}$ T. M. Griffin and I.P. Stotsky Center for the Study of Human Rights, University of Miami, 
Haiti Human Rights Investigation, November 11-21

93 Thomas Griffin, UN in Haiti, Report for Lamp for Haiti, April 2007

${ }^{94}$ A Summary of Findings of the US Labor and Human Rights Delegation to Haiti, S Donnelly, 12 July 2005 (n 8)

${ }^{95}$ Interviews with residents of Bwa Nef, Site Solèy April and November 2016 (n 10)

96 W Dorn, 'Intelligence-led Peacekeeping: The United Nations Stabilization Mission in Haiti (MINUSTAH), 2006-07’ (n 78)

${ }^{97}$ Interviews with residents of Bwa Nef, Site Solèy April and November 2016 (n 10)

${ }^{98}$ Ibid

${ }^{99}$ Report of the Panel on United Nations Peace Operations A/55/305-S/2000/809 August 21, 2000, paragraph 62

${ }^{100}$ ICRC, Violence and the Use of Force (n 15) page 8

${ }^{101}$ Peacekeepers may also use force in 'defence of the mandate' a concept first proposed in United Nations, Report of the Secretary-General on the implementation of Security Council resolution 340 (1973), UN document S/11052/Rev.1, 27 October 1973. The United Nations Capstone Doctrine explains that the traditional 'notion of self-defense has subsequently come to include resistance to attempts by forceful means to prevent the peacekeeping operation from discharging its duties under the mandate of the Security Council.' United Nations Peacekeeping Operations Principles and Guidelines (n 45), page 34.

${ }^{102}$ N Blokker, 'Ch. 9 Outsourcing the Use of Force: Towards More Security Council Control of Authorized Operations?' (n 32) page 211

${ }^{103}$ Note to the Under-Secretary-General of the Department of Peacekeeping Operations, published in the United Nations Juridical Yearbook, 2003, pages 538-9

${ }^{104}$ S/RES 154230 April 2004

${ }^{105}$ ICRC, Violence and the Use of Force (n 15) page 8

106 Protocol Additional to the Geneva Conventions of 12 August 1949 and relating to the Protection of Victims of Non-International Armed Conflicts, (Geneva 1977) paragraph 1 (2)

${ }^{107}$ ICRC, Commentary on the First Geneva Convention: Convention (I) for the Amelioration of the Condition of the Wounded and Sick in Armed Forces in the Field, 2nd edition, 2016, paragraph 386

Common article 3 is the provision that deals with non-international armed conflict. 
${ }^{108}$ Final Report on the Meaning of Armed Conflict in International Law, (n 16), page 28

109 Ibid, page 4

${ }^{110}$ Ibid, page 1

${ }^{111}$ Ibid, page 1

112 Prosecutor v. Tadić, IT-94-1-AR72, Appeals Chamber, Decision on the Defence Motion for Interlocutory Appeal on Jurisdiction, 2 October 1995, paragraph 70

${ }^{113}$ Final Report on the Meaning of Armed Conflict in International Law, (n 16), page 30

${ }^{114} \mathrm{~N}$ Melzer Interpretive Guidance on the Notion of Direct Participation in Hostilities in International Humanitarian Law (ICRC 2009), page 32

115 Bulletin on Observance by United Nations Forces of International Humanitarian Law, (1999) UN Doc ST/SGB/1999/13

${ }^{116}$ D Murray, D Akande, F Hampson, C Garraway, N Lubell, E Wilmhurst, Practitioner's Guide to Human Rights Law in Armed Conflict (n 15), page 262

${ }^{117} \mathrm{~N}$ Melzer, Interpretative Guidance on the Notion of Direct Participation in Hostilities under International Humanitarian Law (n 115), page 62

${ }^{118}$ R McLaughlin, The Use of Lethal Force by Military Forces on Law Enforcement Operations - Is there Lawful Authority? (2009) 37 Federal Law Review 441, at page 446

${ }^{119}$ Protocols I additional to the Geneva Conventions, 8 June 1977, Article 50; The ICJ has stated that '[i]n principle, the right not arbitrarily to be deprived of one's life applies also in hostilities. The test of what is an arbitrary deprivation of life, however, then falls to be determined by the applicable lex specialis, namely, the law applicable in armed conflict which is designed to regulate the conduct of hostilities.' Legality of the Threat or Use of Nuclear Weapons, Advisory Opinion, July 8, 1996, ICJ Rep. 1996, para 25

${ }^{120}$ Protocol I additional to the Geneva Conventions, 8 June 1977, Article 50

${ }^{121} \mathrm{~N}$ Melzer, Interpretative Guidance on the Notion of Direct Participation in Hostilities under International Humanitarian Law (n 115), page 16

122 Ibid, page 62

${ }^{123}$ Ibid, page 62

124 'Towards a Post-MINUSTAH Haiti: Making an Effective Transition: Latin America/Caribbean Report N44,' International Crisis Group, 2 August 2012, page 16; C Call and G Sorensen, U.N. Operations and State-building: A Case Study of Haiti, Center on 
International Cooperation, May 2009, page 5, cited by the UN Department of Peacekeeping Operations in its own report Second Generation Disarmament, Demobilization, and

Reintegration Practices in UN Peacekeeping Operations (UN DPKO, Office of Rule of Law and Security Institutions 2010) page 67

125 S/RES 2149 April 2014, paragraphs 30 (a) (iv) and 40

126 S/RES/2100 (2013) 25 April 2013

${ }^{127}$ ICRC, Violence and the Use of Force, (n 15), page 37

${ }^{128}$ Ibid, page 45

${ }^{129}$ D Murray, D Akande, F Hampson, C Garraway, N Lubell, E Wilmhurst, Practitioner's Guide to Human Rights Law in Armed Conflict (n 15) page 260

${ }^{130}$ Ibid, page 261

${ }^{131}$ L Hanikainen, Peremptory Norms (Jus Cogens) in International Law: Historical Development, Criteria, Present Status (Finnish Lawyers' Publishing Company, 1988) pages 516-17; KM Larsen, The Human Rights Treaty Obligations of Peacekeepers (Cambridge University Press, 2012), pages 323-333; A. Orakhelashvili, 'The Impact of Peremptory Norms on the Interpretation and Application of United Nations Security Council Resolutions,' EJIL, Vol. 16, Issue 1, 58; Jordan J Paust, 'The UN is Bound by Human Rights: Understanding the Full Reach of Human Rights, Remedies and Nonimmunity' (2010) 51 Harvard Intl L J Online www.law.harvard.edu/studorgs/ilj

132 J Paust, 'The Right to Life in Human Rights Law and the Law of War' (2002) 65 Saskatchewan L Rev 412, 412-13; KM Larsen, The Human Rights Treaty Obligations of Peacekeepers (n 131), 323-33

${ }^{133}$ Basic Principles on the Use of Force and Firearms by Law Enforcement Officials (n 14), paragraph 9.

134 Ibid, paragraph 8

135 Adopted by the General Assembly in its resolution 34/169 (1979). See also, Principles on the Effective Prevention and Investigation of Extra-legal, Arbitrary and Summary Executions, E.S.C Res. 1989/65, 24 May 1989.

${ }^{136}$ Report of the Special Rapporteur on extrajudicial, summary or arbitrary executions, Christof Heyns A/HRC/26/36 1 April 2014, paragraph 8; The Basic Principles were cited by the European Court of Human Rights in Nachova v Bulgaria, Applications nos. 43577/98 and 43579/98, 6 July 2005, paragraphs 71-74

${ }^{137}$ Ibid, page 43 
${ }^{138}$ ICRC Expert Meeting Report, The Use of Force in Armed Conflicts: Interplay between the Conduct of Hostilities and Law Enforcement Paradigms November 2013 page 7

http://www.icrc.org/eng/assets/files/publications/icrc-002-4171.pdf.

${ }^{139}$ Report of the Special Rapporteur on extrajudicial, summary or arbitrary executions, Christof Heyns A/HRC/26/36 1 April 2014; paragraph 38

${ }^{140}$ Ibid, paragraph 58

${ }^{141}$ Ibid, paragraphs 74 and 145

${ }^{142}$ Extrajudicial, summary or arbitrary executions: Report of the Special Rapporteur, Philip Alston, E/CN.4/2006/53/Add.1 27 March 2006, page 323

143 Ibid

${ }^{144}$ Interview with Philip Alston at New York University Law School November 2016

${ }^{145}$ D Murray, D Akande, F Hampson, C Garraway, N Lubell, E Wilmhurst, Practitioner's Guide to Human Rights Law in Armed Conflict (n 15), page 261

${ }^{146}$ Ibid, page 125

${ }^{147}$ Ibid, pages 136 and 124

${ }^{148}$ Interview with Mona Kahlil, currently working with Independent Diplomat whilst on a career break from the Office of the Legal Counsel, UNHQ, United Nations, New York, June 2016 and confirmed in writing by email.

149 ibid

${ }^{150}$ Interview with Stephane Wohlfahrt, Senior Officer, Office of the Legal Counsel, UNHQ, United Nations, New York, June 2016

${ }^{151}$ Moreover, the perspective through which this problem is viewed may shape the way arguments are presented in an interview context. Currently a major issue of concern at UN Headquarters is the persistent failure of UN troops to intervene proactively to protect civilians.

152 The Practitioner's Guide to Human Rights Law in Armed Conflict uses the term "security operations" in in order to denote activities carried "which are largely of the nature of law enforcement but since they are carried out within armed conflict...the term law enforcement was not thought appropriate.' D Murray, D Akande, F Hampson, C Garraway, N Lubell, E Wilmhurst, Practitioner's Guide to Human Rights Law in Armed Conflict (n 15) page 91. However law enforcement operation is the more common term and is used by both the International Committee of the Red Cross (ICRC) and the International Law Association (ILA)). 
${ }^{153}$ Ibid, page 136

${ }^{154}$ Principles of UN peacekeeping:

http://www.un.org/en/peacekeeping/operations/principles.shtml

${ }^{155}$ UN Guidelines for the Development of Rules of Engagement and Sample ROE for UN Peacekeeping Operations, Jean-Marie Guehenno, December $1^{\text {st }}$ 2000; See also United Nations, Guidelines for the development of ROE for UNPKO, UN document MD/FGS/0220.0001, May 2002 (provisional), Attachment 1, published in T Findlay, The Use of Force in Peace Operations (Oxford University Press 2002), page 425

156 Ibid; UN Guidelines for the Development of Rules of Engagement and ROE for UN Peacekeeping Operations, Jean-Marie Guehenno, December $1^{\text {st }} 2000$ (n 156)

157 This sample rule, which appears to have some words missing, was implemented in the ROE for UNTAET as 'Use of force, up to, and including deadly force, against any person and/or group that limits or intends to limit the freedom of movement of UNTAET personnel is authorized.' Rules of Engagement for the Military Component of the United Nations Mission in East Timor, 2000, published in Law and Military Operations in East Timor Feb 2000- May 2002 Lessons Learnt for Military Officers (Australia Defence Force Military Law Centre and Asia Pacific Military Law Centre 2002)

158 Ibid

${ }^{159}$ Ibid, page 48

160 Rules of Engagement for the Military Component of the United Nations Mission in East Timor, 2000 (n 158)

${ }^{161}$ Rules of Engagement for the for the Military Component of the United Nations

Multidimensional Integrated Stabilization Mission in the Central African Republic, Annex E Rules of Engagement for MINUSCA Troops Aide Memoire (Soldiers' Blue Card), UN Military Planning Service, August 2014 (draft, awaiting signature of Hervé Ladsous, confidentially on file with author)

162 Ibid

${ }^{163}$ Ibid, Annex C

164 The copy of the MINUSCA ROE on file with the author is a draft version drawn up to be sent to Hervé Ladsous for his signature

${ }^{165} \mathrm{~S} /$ Res 2149 April 2014, paragraphs 29, 30 (a) (iv) and 40

${ }^{166}$ Rules of Engagement for the Military Component of the United Nations Stabilization Mission in Haiti, 28 June 2004, signed by Jean-Marie Guehenno, Under-Secretary General for 
Peacekeeping Operations (confidentially on file with author).

167 S/RES 154230 April 2004

${ }^{168}$ Resolution 1542 also mandates the mission 'to assist the Transitional Government in extending State authority throughout Haiti and support good governance at local levels' but this provision is in Part III of the mission's mandate: only Part I is adopted under Chapter VII. The task of assisting the Transitional Government extend State authority throughout Haiti is listed in MINUSTAH's ROE as one of eight situations in which the mission may use 'force beyond selfdefence' - but the ROE listing does not distinguish between the tasks that are mandated under Chapter VII and those that are not.

${ }^{169}$ Rules of Engagement for MINURCAT Troops, annexed to Rules of Engagement for the Military Component of the United Nations Mission in the Central African Republic and Chad, February 2009 (draft, awaiting signature of Alain Le Roy, confidentially on file with author)

${ }^{170}$ Rules of Engagement for the Military Component of the United Nations Stabilization Mission in Haiti (n 167)

${ }^{171}$ Provided that the weapon state does not exceed the authority of Security Council 1542 and subsequent mandating resolutions: Rules of Engagement for the Military Component of the United Nations Stabilization Mission in Haiti (n 167) Annex D Weapon States

172 'Rights Up Front' (May 2014) http://www.un.org/sg/humanrightsupfront/. Although the initiative 'is designed primarily for settings where the UN does not have a political or peacekeeping mission ' the Secretary-General's 2014 Aide Memoire to the plan (on file with this author) states that "its spirit can and should also be applied to "mission settings."

${ }^{173}$ Report of the High-level Independent Panel on Peace Operations on uniting our strengths for peace: politics, partnership and people, A/70/95-S/2015/446, 17 June 2015, paragraph 81(d) (iii)

${ }^{174}$ D Murray, D Akande, F Hampson, C Garraway, N Lubell, E Wilmhurst, Practitioner's Guide to Human Rights Law in Armed Conflict (n 15), pages 136 and 124

175 The medical teams of some troop contributing states do provide short-term emergency medical aid to host state victims of violence on an ad hoc basis, to the extent that they have the resources; but the UN provides no central funding for this and does not have a clear policy on it. J Tobin, 'The challenges and ethical dilemmas of a military medical officer serving with a peacekeeping operation in regard to the medical care of the local population,' (2005) J Med Ethics Vol. 31, 571, at page 1

${ }^{176}$ UN HAITI/GUENNO 28 July 2005

http://www.unmultimedia.org/avlibrary/asset/U050/U050729b/ 